\title{
The influence of climate conditions and fertilizer rates calculated by different methods on spring wheat crop
}

\author{
Gediminas Staugaitis, \\ Loreta Aleknavičienė, \\ Zita Brazienè, \\ Antanas Marcinkevičius \\ Lithuanian Research Centre \\ for Agriculture and Forestry, \\ Instituto Ave. 1, \\ 58344 Akademija, \\ Kédainiai District, Lithuania \\ Email:agrolab@agrolab.lt
}

In 2011-2015, at the Rumokai Experiment Station of the Lithuanian Research Centre for Agriculture and Forestry research was carried out with spring wheat on Bathihypogleyi-Calc(ar)ic Luvisol (LVk-gld-w) with predominant silt loam ant clay loam. The main aim was to determine the influence of climate conditions and fertilizer rates calculated by different methods on spring wheat. Five years of research have shown that using the Fertilization Program "Derlius" of the Agrochemical Laboratory at the Lithuanian Research Centre for Agriculture and Forestry, during spring wheat fertilization the nitrogen fertilizers were less consumed by $15.8 \%$, phosphorus by $81.9 \%$ and potassium by $41.1 \%$ compared with fertilization for obtaining the planned $5 \mathrm{t}$ ha- 1 spring wheat grain yield. Also, the studies have shown that climatic conditions in the eastern part of the Baltic Sea greatly affect the yield of spring wheat. The yield of wheat grain and straw, and the number of productive stems correlated with the amount of precipitation and the sum of active temperatures in spring wheat $\mathrm{BBCH} 21-37$ growth stages. A negative correlation was established in the growth stages $\mathrm{BBCH}$ 61-89 between higher rainfall and spring wheat yields. The average data from the five years of research showed that the sum of active temperatures during wheat growth increased nitrogen, phosphorus and potassium in the straw, and phosphorus and potassium concentrations in the grain.

Keywords: fertilization, spring wheat, weather conditions, nitrogen, phosphorus, potassium

\section{INTRODUCTION}

Winter wheat occupies large areas in northern and central Europe, but sowing and wintering conditions in the eastern part of the Baltic Sea are often unfavourable due to climate change anomalies. As an alternative to this, spring wheat is rapidly growing. In Lithuania alone, over the past ten years, the area of wheat has increased threefold. Although the yield of spring wheat is lower than that of winter wheat, but fertile, varieties and good agricultural technology conditions allow it to have higher yields from harvesting (Smith et al., 2017). Because of a weakly developed root system (Narayanan, 2014), these plants also have difficulty in absorbing nutrients from the soil and are sensitive to short-term droughts. Thus, the weather conditions have a significant impact on the yield and quality of spring wheat (Fischer, 2016). The weather in the vegetation season can affect to $55 \%$ of the yield fluctuation amplitude, and fluctuations in the chemical composition are also affected by the heat and moisture regimes (Campiglia et al., 2015; Mondal et al., 2016). Additionally, the yields can be significantly increased by fertilization, because the fertilizer affects $22-30 \%$ of the yield variation, while crop rotation affects $5-12 \%$, and agricultural engineering affects 12-24\% (Hawkesford, 2014; Jiangang et al., 2015). Mineral fertilizers in the soil boost the levels and concentrations of the nutrient elements (e.g. N, P and K) that are easily 
available to the plants. However, regardless of the soil's agrochemical composition, intense fertilization with high rates of fertilizers, especially phosphorus and ammonium nitrogen (Bücking et al., 2015), reduces the formation of mycorrhiza (Nouri et al., 2014). Therefore, plants have difficulties in absorbing water from the soil, especially in times of drought, and decompose fewer amounts of organic compounds (García et al., 2008). Water is a natural solvent for chemical elements and is the factor that most limits the yields (Parida et al., 2007; Dias, Bruggemann, 2010). However, the sufficient moisture content increases the mobility of mineral elements through the soil profile (Pranckietiene et al., 2015), and their uptake by the plants. For example, wheat (Grant et al., 2005) absorbs phosphorus and potassium (Karamanos, 2013; Satyaprakash et al., 2017) by diffusion; thus, if the water content in the root zone of plants is reduced, it will begin to experience a shortage of these macronutrients. Drought reduces the nitrogen's mobility and assimilation, slowing down the growth of the plants and promoting the development of chlorosis (Mahieu et al., 2009). However, with an abundant and intense precipitation (especially $30 \mathrm{~mm}$ or more over a short period), a high content of mineral nitrogen accumulates in the upper soil layer $(0-30 \mathrm{~cm})$ and easily migrates into the subsoil or even deeper (Czaban et al., 2014; Žičkienè et al., 2015). Phosphorus leaching is growing due to application of more than the rational fertilization, and the leaching of potassium occurs because of higher fertilizer rates in wetter soils. Potassium fixation increases in dry soils (Zörb et al., 2014). So, in order to grow more spring wheat yields and tightening the requirements for nature protection, it is important to correctly assess local meteorological conditions, soil properties and the amount of nutrients present in it. It is also important to evaluate the influence of these factors on different stages of spring wheat growth. Knowing this, it would be possible to apply fertilizer and antistress measures during spring wheat growth.

In the eastern part of the Baltic Sea there are not many conducted field experiments to determine the impact of climatic conditions and fertility rates calculated by different methods on spring wheat. That was our main aim.

\section{MATERIALS AND METHODS}

The field experiment was conducted at the $\mathrm{Ru}$ mokai Experimental Station of the Lithuanian Research Centre for Agriculture and Forestry in 2011-2015.

Soil properties. The experiment was conducted on Bathihypogleyi-Calc(ar)ic Luvisol (LVk-gld-w). The soil texture was composed of silt loam and clay loam. The top of the carbonate horizon and the gleyicity traces were determined at a $60 \mathrm{~cm}$ depth. The $\mathrm{pH}$ value in arable soil ranged from 6.4 to 7.4. The content of the plant-available $\mathrm{P}_{2} \mathrm{O}_{5}$ ranged from 239 to $388 \mathrm{mg} \mathrm{kg}^{-1}$, and the content of the plant-available $\mathrm{K}_{2} \mathrm{O}$ ranged from 183 to $272 \mathrm{mg} \mathrm{kg}{ }^{-1}$. In the spring, before sowing wheat in a $0-60 \mathrm{~cm}$ layer of the soil, the mineral nitrogen $\left(N_{\min }\right)$ level ranged from 28.1 to $110.5 \mathrm{~kg} \mathrm{ha}^{-1}$.

Soil samples were collected from a $0-20 \mathrm{~cm}$ soil layer for the determination of the $\mathrm{pH}$, plantavailable phosphorus and potassium content during every repetition from 19 March - 20 April. At the same time, soil samples were collected from the $0-30$ and $30-60 \mathrm{~cm}$ soil layers for the determination of mineral nitrogen. The soil $\mathrm{pH}$ was determined in a $1 \mathrm{~N} \mathrm{KCl}$ extraction using the potentiometric method (ISO 10390:2005); the plantavailable phosphorus and potassium contents were determined with the Egner-Riehm-Domingo (A-L) method; and the $N_{\min }$ content was determined in a $1 \mathrm{~N} \mathrm{KCl}$ extraction (sample and solution ratio 1:2.5) using the colorimetric method.

The tests were performed with the spring wheat cultivar 'Triso', with a seeding rate of 4.04.5 million $\mathrm{ha}^{-1}$, which was sown between $10-26$ April. The initial test field size was $36 \mathrm{~m}^{2}$, while the accounting size was $26.4 \mathrm{~m}^{2}$. Each option had 4 replications where the variants were arranged randomly within the replications. The research scheme was composed of the following: 1) control-fertilization for obtaining the planned $5 \mathrm{t} \mathrm{ha}^{-1}$ spring wheat grain yield by fertilising with $\mathrm{N}_{151} \mathrm{P}_{52} \mathrm{~K}_{105}$ every year (Fertilization 1) (Zorn et al., 2007); and 2) fertilization for obtaining the planned $5 \mathrm{t} \mathrm{ha}^{-1}$ grain yield while also taking into consideration the soil's agrochemical analysis - mineral nitrogen, mobile phosphorus and potassium present in the soil (Fertilization 2) (Table 1). This is based on multiannual testing (Management of Agroecosystem Components, 
2010) of the Fertilization Program "Derlius" newly created at the Lithuanian Research Centre for Agriculture and Forestry Agrochemical Laboratory and used on farms, but not yet tested by experiments. In this program, the nitrogen rate for obtaining the planned yield is multiplied by the coefficient, which is calculated according to the formula: $y=-0.05 x+1.35$, where $x$ is the nitrogen concentration $N_{\text {min }}\left(\mathrm{mg} \mathrm{kg}^{-1}\right)$ in the soil at depths $0-60 \mathrm{~cm}$. The phosphorus and potassium fertilizer rates are calculated according to the formulas, respectively: $y=-0.0044 x+1.3795$ and $y=-0.0045 x+1.517$, where $x$ is the concentration of available $\mathrm{P}_{2} \mathrm{O}_{5}$ and available $\mathrm{K}_{2} \mathrm{O}$ in the soil at depths $0-20 \mathrm{~cm}$. When available phosphorus and potassium concentrations in the soil are higher than $300 \mathrm{mg} \mathrm{kg}^{-1}$, phosphorus and potassium fertilizers are not to be used in summer wheat.

Table 1. Fertilization rates of nitrogen, phosphorus and potassium in the second variant of the experiment (Fertilization 2) according to soil agrochemical studies

\begin{tabular}{|c|c|c|c|c|}
\hline \multirow{3}{*}{ Year } & \multicolumn{4}{|c|}{ Fertilization, $\mathrm{kg} \mathrm{ha}^{-1}$} \\
\hline & \multicolumn{2}{|r|}{$\mathbf{N}$} & $\mathbf{P}_{2} \mathbf{O}_{5}$ & $\mathrm{~K}_{2} \mathrm{O}$ \\
\hline & Pre-sowing & Supplementary & \multicolumn{2}{|c|}{ Pre-sowing } \\
\hline 2011 & 119 & 40 & 13 & 68 \\
\hline 2012 & 96 & 40 & 0 & 37 \\
\hline 2013 & 13 & 40 & 8 & 68 \\
\hline 2014 & 103 & 40 & 8 & 68 \\
\hline 2015 & 105 & 40 & 18 & 68 \\
\hline
\end{tabular}

In the spring, before the crop sowing, all of the estimated phosphorous and potassium rates was spread on the soil; and from the estimated nitrogen fertilizer rate, $40 \mathrm{~kg} \mathrm{ha}^{-1}$ of nitrogen was spread on the area in the $\mathrm{BBCH} 31-$ 32 growth stages of spring wheat, i.e. between 23 May - 3 June. Spring wheat was fertilized with ammonium nitrate, potassium chloride and diammonium phosphate.

Statistical analyses of the yield and the plant biometric data were performed using the analysis of variance (ANOVA). The correlation analysis was carried out in order to evaluate the interdependence of the test data, and the tables present only those equations where the correlation coefficient is higher than 0.3 .
Weather conditions. The precipitation in 20112015 during the growing season for spring wheat was distributed very unevenly, and the average daily temperature was higher than in the periods of 1981-2010 (Table 2). In 2011, dry periods prevailed during the spring wheat germination; therefore, the crop germination was extended and uneven. The temperatures during the tillering stage were favourable, and the plants formed the optimal crop density, but at the beginning of milky maturity and during harvesting the ears formed smaller grains because of significant precipitation. Favourable weather for spring wheat germination and tillering prevailed in the beginning of 2012. Therefore, the largest number of productive stems per unit of area was formed throughout this observation period. However, heavy rains and strong wind at the beginning of July wiped out the crops and the spring wheat formed a smaller grain harvest than expected. The year 2013 was characterized by the lowest April average temperature of $+5.7^{\circ} \mathrm{C}$ for the period of 2011-2015, and by very wet conditions. The soil dried poorly and, as a result, the sowing of spring crops started 2-3 days later than in other years. There were several heavy rains in May, and a crust was formed on the surface of the soil which bent the sprouts to the ground. The wet early June also affected the spread of fungal diseases (Blumeria graminis). In July, the weather was favourable for the spring wheat grain formation and maturation. In April 2014, the moisture in the soil was sufficient for the spring wheat germination and tillering. However, in July, because of an uneven distribution of rainfall and higher air temperatures the side stem formations were reduced and the crop thinned out. However, this year the grain yield was the highest during the observation period. In 2015, the weather was favourable for spring wheat sowing and germination. But the end of May and the 1st and 2nd ten-day periods of June were very droughty. So the soil dried up while the wheat crop was rare. This was the only year out of the five years when the crop was rare and the spring wheat formed the least number of productive stems, but the ears had more grains and they were much heavier than in the other years of the study. 
Table 2. The mean daily temperature values and the amount of rainfall of ten-day periods during the spring wheat growing season and climate normal (Kybartai Meteorological Station, 1981-2010)

\begin{tabular}{|c|c|c|c|c|c|c|c|c|c|c|c|c|c|c|c|}
\hline \multirow{3}{*}{ Year } & \multicolumn{15}{|c|}{ Air temperature, ${ }^{\circ} \mathrm{C}$} \\
\hline & \multicolumn{3}{|c|}{ April } & \multicolumn{3}{|c|}{ May } & \multicolumn{3}{|c|}{ June } & \multicolumn{3}{|c|}{ July } & \multicolumn{3}{|c|}{ August } \\
\hline & I & II & III & I & II & III & I & II & III & I & II & III & I & II & III \\
\hline 2011 & 7.4 & 6.8 & 13.6 & 8.5 & 13.8 & 15.1 & 20.6 & 15.4 & 17.3 & 18.7 & 19.6 & 19.3 & 18.1 & 17.1 & 17.9 \\
\hline 2012 & 2.0 & 7.8 & 13.8 & 12.6 & 12.3 & 15.8 & 12.8 & 16.3 & 15.7 & 21.1 & 16.6 & 20.3 & 18.5 & 16.0 & 15.8 \\
\hline 2013 & -0.4 & 8.5 & 9.1 & 14.4 & 16.7 & 15.1 & 18.1 & 17.2 & 18.0 & 18.5 & 17.6 & 19.0 & 21.0 & 18.1 & 15.1 \\
\hline 2014 & 5.6 & 8.6 & 12.9 & 9.0 & 13.7 & 17.3 & 16.7 & 14.4 & 13.4 & 19.4 & 18.8 & 22.5 & 22.4 & 17.7 & 14.0 \\
\hline 2015 & 4.3 & 7.2 & 10.8 & 11.6 & 10.6 & 14.1 & 15.1 & 15.3 & 15.3 & 19.8 & 16.2 & 17.1 & 21.5 & 18.9 & 20.6 \\
\hline 1981-2010 & 5.5 & 6.8 & 9.7 & 11.6 & 13.2 & 14.0 & 15.5 & 15.2 & 16.2 & 17.6 & 18.2 & 18.3 & 18.5 & 17.7 & 16.2 \\
\hline \multicolumn{16}{|c|}{ Precipitation, $\mathrm{mm}$} \\
\hline 2011 & 24 & 6 & 0 & 16 & 20 & 10 & 2 & 25 & 13 & 49 & 35 & 79 & 59 & 55 & 16 \\
\hline 2012 & 20 & 31 & 4 & 11 & 23 & 11 & 22 & 27 & 49 & 61 & 45 & 12 & 27 & 6 & 13 \\
\hline 2013 & 36 & 7 & 4 & 1 & 11 & 45 & 76 & 3 & 18 & 16 & 41 & 6 & 33 & 12 & 9 \\
\hline 2014 & 12 & 4 & 0 & 24 & 34 & 1 & 12 & 25 & 41 & 36 & 36 & 22 & 10 & 23 & 21 \\
\hline 2015 & 23 & 13 & 10 & 20 & 29 & 5 & 0 & 2 & 15 & 4 & 43 & 29 & 3 & 0 & 3 \\
\hline 1981-2010 & 13 & 11 & 12 & 13 & 11 & 7 & 13 & 17 & 20 & 17 & 29 & 26 & 26 & 31 & 24 \\
\hline
\end{tabular}

\section{RESULTS AND DISCUSSION}

In 2011-2015, the average spring wheat yield was $5.24 \mathrm{t} \mathrm{ha}^{-1}$, and in different years of the study the yield varied from 4.10 to $6.72 \mathrm{t} \mathrm{ha}^{-1}$. According to the average information for the five years, the fertilization with the NPK for obtaining the planned yield of grain compared with the fertilization according to the results of the soil agrochemical tests did not result in a statistically reliably increase in the yields of the grain and straw: the average grain yield increase was merely $1.1 \%$, while the straw increase was $3.7 \%$ (Table 3). Other indicators also prevailed within the margin of error: the number of productive stems, the number of grains per ear, the 1000 grain weight and the crude protein content in the grain. This indicates that the calculation of summer wheat fertilization rates according to the results of the soil agrochemical tests was fully justified; the yield did not decrease, and the grain quality remained the same, while significantly less fertilizer was used for the plant fertilization: nitrogen $(N)$ 15.8\% less, phosphorus $\left(\mathrm{P}_{2} \mathrm{O}_{5}\right)$ 81.9\% less and potassium $\left(\mathrm{K}_{2} \mathrm{O}\right) 41.1 \%$ less. It was unexpected that in 2013, according to the $N_{\text {min }}$ studies, only $53 \mathrm{~kg} \mathrm{ha}^{-1}$ nitrogen $(N)$ or only 2.8 times less than in the first fertilization variant was used for spring wheat. So, essential grain yields have not diminished. This shows that there are reserves to reduce nitrogen rates, which are ecologically very important. Other European agrochemical laboratories also recommend reducing fertilizer rates when the soil contains many nutrients. However, recommendations are different and get different yields (Fotyma et al., 2008).

In this experiment, our purpose was not only to assess the influence of the fertilizer calculation methods on the productivity of spring wheat, but also to determine the climatic factors (Table 4).

The meteorological conditions influenced the spring wheat grain yield and this is discussed in many publications. Precipitation in the vegetation period can lead to up to $50 \%$ less wheat yield (Rodziewicz et al., 2014; Trnka et al., 2014). In both of the fertilization backgrounds, the spring wheat yields were highly correlated with the precipitation amount in the $\mathrm{BBCH} 21-37$ growth stages $\left(r=0.713^{\star}\right.$ and $\left.r=0.710^{\star}\right)$, and this shows that in that period sufficient soil moisture reserves are very important for the production of spring wheat because water scarcity in soil is one of the most commonly occurring stress factors. It has a negative effect on wheat growth and productivity (Rodziewicz et al., 2014; Tammeorg et al., 
Table 3. Impact of the fertilization with nitrogen $(\mathrm{N})$, phosphorus $\left(\mathrm{P}_{2} \mathrm{O}_{5}\right)$ and potassium $\left(\mathrm{K}_{2} \mathrm{O}\right)$ on the spring wheat yield and the productivity indicators for obtaining the planned yield and according to the soil agrochemical studies

\begin{tabular}{|c|c|c|c|c|c|c|}
\hline \multirow{2}{*}{ Treatment } & \multicolumn{5}{|c|}{ Year } & \multirow[b]{2}{*}{ Average } \\
\hline & 2011 & 2012 & 2013 & 2014 & 2015 & \\
\hline \multicolumn{7}{|c|}{ Grain yield, $\mathrm{t} \mathrm{ha}^{-1}$} \\
\hline Fertilization 1 & 4.10 & 4.55 & 5.28 & 5.72 & 6.72 & 5.27 \\
\hline Fertilization 2 & 4.21 & 4.43 & 5.02 & 5.70 & 6.70 & 5.21 \\
\hline $\mathrm{LSD}_{05}$ & 0.022 & 0.202 & 0.264 & 0.194 & 0.266 & 0.150 \\
\hline \multicolumn{7}{|c|}{ Straw yield, $\mathrm{t} \mathrm{ha}^{-1}$} \\
\hline Fertilization 1 & 1.81 & 2.61 & 2.21 & 2.02 & 2.40 & 2.15 \\
\hline Fertilization 2 & 1.70 & 2.40 & 2.05 & 2.02 & 2.44 & 2.07 \\
\hline $\mathrm{LSD}_{05}$ & 0.182 & 0.276 & 0.180 & 0.154 & 0.234 & 0.176 \\
\hline \multicolumn{7}{|c|}{ Number of productive stems per $\mathrm{m}^{2}$} \\
\hline Fertilization 1 & 614 & 746 & 590 & 670 & 584 & 641 \\
\hline Fertilization 2 & 594 & 749 & 574 & 657 & 564 & 627 \\
\hline $\mathrm{LSD}_{05}$ & 39.9 & 20.6 & 21.5 & 39.1 & 48.6 & 33.0 \\
\hline \multicolumn{7}{|c|}{ Number of grains per ear } \\
\hline Fertilization 1 & 29 & 30 & 33 & 33 & 37 & 32 \\
\hline Fertilization 2 & 31 & 30 & 31 & 34 & 36 & 32 \\
\hline $\mathrm{LSD}_{05}$ & 1.1 & 1.5 & 1.2 & 2.8 & 2.9 & 0.6 \\
\hline \multicolumn{7}{|c|}{1000 grain weight, $\mathrm{g}$} \\
\hline Fertilization 1 & 35.1 & 35.4 & 38.4 & 35.5 & 43.2 & 37.5 \\
\hline Fertilization 2 & 35.5 & 36.4 & 38.6 & 35.2 & 43.9 & 37.9 \\
\hline $\mathrm{LSD}_{05}$ & 0.91 & 1.19 & 0.90 & 0.91 & 0.92 & 0.67 \\
\hline \multicolumn{7}{|c|}{ Crude protein \% of absolutely dry matter } \\
\hline Fertilization 1 & 17.1 & - & 14.0 & 10.5 & 14.0 & 13.9 \\
\hline Fertilization 2 & 17.5 & - & 12.3 & 10.9 & 13.7 & 13.6 \\
\hline $\mathrm{LSD}_{05}$ & 0.82 & - & 0.87 & 0.78 & 1.24 & 0.62 \\
\hline
\end{tabular}

Table 4 . The correlation between the spring wheat grain yield $\left(\mathrm{tha}^{-1}\right)(y)$ and the meteorological conditions $\left(x_{1}-x_{4}\right)$

\begin{tabular}{ccccc}
\hline Treatment & Regression equation & $\boldsymbol{r}$ & $\boldsymbol{x}_{\min }-\boldsymbol{x}_{\max }$ \\
\hline & (1) Precipitation $(\mathrm{mm})$ in the BBCH $21-37$ growth stages $\left(x_{1}\right)$ & \\
\hline Fertilization 1 & $y=0.0134 x+3.7487$ & $0.713^{\star}$ & $48-134$ \\
\hline Fertilization 2 & $y=0.0125 x+3.7954$ & $0.710^{*}$ & $48-134$ \\
\hline \multicolumn{5}{c}{ (2) Precipitation $(\mathrm{mm})$ in the BBCH 61-89 growth stages $\left(x_{2}\right)$} \\
\hline Fertilization 1 & $y=-0.0142 x+6.6104$ & $0.733^{\star}$ & $98-174$ \\
\hline Fertilization 2 & $y=-0.0131 x+6.438$ & $0.722^{\star}$ & $98-174$ \\
\hline
\end{tabular}

(3) Sum of the active temperatures $\left(\geq 10^{\circ} \mathrm{C}\right)$ in the $\mathrm{BBCH} 21-37$ growth stages $\left(x_{3}\right)$

\begin{tabular}{llll} 
Fertilization 1 & $y=0.0058 x+1.4918$ & $0.776^{* *}$ & $472-676$ \\
\hline Fertilization 2 & $y=0.0057 x+1.5526$ & $0.808^{\star *}$ & $472-676$
\end{tabular}

(4) Sum of the active temperatures $\left(\geq 10^{\circ} \mathrm{C}\right)$ in the BBCH 61-89 growth stages $\left(x_{4}\right)$

\begin{tabular}{cccc}
\hline Fertilization 1 & $y=0.0037 x+1.5482$ & 0.468 & $377-988$ \\
\hline Fertilization 2 & $y=0.0037 x+1.4592$ & 0.509 & $377-988$ \\
\hline
\end{tabular}

* The indicator corresponds to $05 \%$;

** The indicator corresponds to $01 \%$. 
2014). Furthermore, a reliable negative dependence on the precipitation amount was obtained in the BBCH $61-89$ growth stages $\left(r=0.733^{\star}\right.$ and $\left.r=0.722^{\star}\right)$, when the wheat was affected by rainfalls in June and July. This indicates that the soil's moisture and the amount of rainfall occurring in this period is very important for spring wheat (Rodziewicz et al., 2014) in this climatic zone, until the end of the plant stem elongation. Meanwhile, at a later stage, when the plant roots are already deeply rooted, the plants often suffer not from a lack of rainfall but from an excessive amount of precipitation during rainfalls.

Higher amounts of active temperatures $\left(\geq 10^{\circ} \mathrm{C}\right)$ at the beginning and the end of the spring wheat growth stimulated an increase in the grain yield. This result was reliably obtained in the two fertilization backgrounds in the $\mathrm{BBCH}$ 21-37 $\left(r=0.776^{*}\right.$ and $\left.r=0.808^{\star}\right)$ and BBCH $61-89$ $(r=0.468$ and $r=0.509)$ growth stages. It means that higher air temperature of about $20-25^{\circ} \mathrm{C}$ is considered to be optimum for growth and development in these temperate zones is very important for spring wheat during the germination and tillering stages (Hossain et al., 2012) which coincides with the second half of April and the month of May. The second period that is important for spring wheat is after flowering, when rainy and cool weather will worsen the grain ripening process (Yadav, Ellis, 2016).

The cultivar 'Triso' of spring wheat is not lush; therefore, the average straw yield in the study period of 2011-2015 was 2.11 t ha- $\mathrm{t}^{-1}$ and in some years it ranged from just 1.70 to $2.61 \mathrm{t} \mathrm{ha}^{-1}$. The biggest straw yield in all the years of study occurred in the warm and normally moist year of 2012.

The plant height and biomass yield were partially influenced by the interaction effects with environment, and this influence decreased gradually with the plant development (Dong et al., 2015). In this experiment the correlation analysis showed that the straw yield strongly correlated with the precipitation amount in the $\mathrm{BBCH} 37-$ 69 growth stages $\left(r=0.687^{\star}\right.$ and $\left.r=0.731^{\star}\right)$ (Table 5). Meanwhile, in the previous BBCH 21-37 growth stages, we did not identify any significant impact from the precipitation; while in the subsequent $\mathrm{BBCH}$ 61-89 growth stages the larger amount of precipitation decreased the straw yield $\left(r=0.676^{\star}\right.$ and $\left.r=0.811^{\star *}\right)$. This shows

Table 5. The correlation between the spring wheat straw yield $\left(\mathrm{t} \mathrm{ha}^{-1}\right)(y)$ and the meteorological conditions $\left(x_{1}-x_{4}\right)$ and the soil's agrochemical properties $\left(x_{5}\right)$

\begin{tabular}{|c|c|c|c|}
\hline Treatment & Regression equation & $r$ & $x_{\min }-x_{\max }$ \\
\hline \multicolumn{4}{|c|}{ (1) Precipitation $(\mathrm{mm})$ in the BBCH $37-69$ growth stages $\left(x_{1}\right)$} \\
\hline Fertilization 1 & $y=0.0048 x+1.8592$ & $0.687^{\star}$ & $16-133$ \\
\hline Fertilization 2 & $y=0.0042 x+1.7716$ & $0.731^{\star}$ & $16-133$ \\
\hline \multicolumn{4}{|c|}{ (2) Precipitation $(\mathrm{mm})$ in the BBCH $61-89$ growth stages $\left(x_{2}\right)$} \\
\hline Fertilization 1 & $y=-0.0066 x+2.9522$ & $0.676^{*}$ & $11-174$ \\
\hline Fertilization 2 & $y=-0.0066 x+2.8282$ & $0.811^{\star *}$ & $11-174$ \\
\hline \multicolumn{4}{|c|}{ (3) Sum of the active temperatures $\left(\geq 10^{\circ} \mathrm{C}\right)$ in the $\mathrm{BBCH} 37-69$ growth stages $\left(x_{3}\right)$} \\
\hline Fertilization 1 & $y=0.002 x+1.4977$ & $0.739^{\star}$ & $132-511$ \\
\hline Fertilization 2 & $y=0.0013 x+1.5894$ & 0.602 & $132-511$ \\
\hline \multicolumn{4}{|c|}{ (4) Sum of the active temperatures $\left(\geq 10^{\circ} \mathrm{C}\right)$ in the $\mathrm{BBCH} 61-89$ growth stages $\left(x_{4}\right)$} \\
\hline Fertilization 1 & $y=-0.0032 x+5.0568$ & $0.807^{\star *}$ & $377-988$ \\
\hline Fertilization 2 & $y=-0.023 x+4.159$ & $0.710^{*}$ & $377-988$ \\
\hline \multicolumn{4}{|c|}{ (5) $N_{\min }$ content in the soil 0-60 cm $+N_{\text {Fertilizers }}\left(\mathrm{kg} \mathrm{ha}^{-1}\right)\left(x_{5}\right)$} \\
\hline Fertilization 1 & $y=0.0051 x+1.0714$ & 0.577 & $179-262$ \\
\hline Fertilization 2 & $y=0.0063 x+0.8574$ & 0.472 & $164-213$ \\
\hline
\end{tabular}

* The indicator corresponds to $05 \%$;

** The indicator corresponds to $01 \%$. 
that the results are the same as for the grain: humidity is very important for the straw growth in the BBCH 37-69 growth stages, but in later stages higher quantities or an excess of precipitation can increase the risk of plant lodging and the yields are lower. A similar correlation was obtained with the sum of active temperatures $\left(\geq 10^{\circ} \mathrm{C}\right)$, which influenced the straw yield growth in the $\mathrm{BBCH} 37-69$ growth stages $\left(r=0.739^{*}\right.$ and $r=0.602$ ) but led to a yield reduction in the $\mathrm{BBCH} 61-89$ growth stages $\left(r=0.807^{\star \star}\right.$ and $r=0.710^{\star}$ ).

We did not receive any correlation between the amount of $N_{\min }$ in the soil with mineral nitrogen fertilizers inserted in the soil and the grain yield. The correlation received with straw yields is statistically unreliable.

In the five-year experimental study, we aimed to analyse the effects of the precipitation amount and the sum of active temperatures on various elements of the spring wheat productivity: the number of productive stems, the grain number per ear and the 1000 grain weight. Precipitation and active temperatures are the main environmental factors responsible for plant growth and development processes (Nakayama et al., 2007). According to many researchers, plants are more sensitive to moisture shortages in early growth periods (Kawakami et al., 2006; Tesfaye et al., 2006). So, in our experiment the most important of them was the precipitation amount $(\mathrm{mm})$, where a correlation between the precipitation amount in the $\mathrm{BBCH}$ 21-89 growth stages $(x)$ and the number of productive stems $\mathrm{pcs} / \mathrm{m}^{-2}(y)$ was obtained in both of the fertilization backgrounds, with $y=3.1373 x-192.7$, $r=0.790^{* *}$ and $y=3.6753 x-353.46, r=0.933^{* *}$, respectively. There was also a correlation between the precipitation quantity $(\mathrm{mm})$ in the $\mathrm{BBCH} 21-$ 37 and $\mathrm{BBCH}$ 37-69 growth stages $\left(x_{1}\right.$ and $x_{2}$ ), and the number of grain units per ear $(y)$, with $y=0.0202 x_{1}+19.453, r=0.883^{*}$ and $y=0.0108 x_{2}+25.074, r=0.683$, respectively. Finally, a correlation was recorded between the precipitation quantity $(\mathrm{mm})$ in the $\mathrm{BBCH} 21-37$ growth stages $(x)$ and the 1000 grain weight $(y)$, with $y=0.0264 x+34.078, r=0.883^{*}$ and $y=0.0237 x+34.363, r=0.568$, respectively. From this, it follows that spring wheat is sensitive to a lack of moisture during the tillering and stem elongation phases, which can result in a reduced number of productive stems and of grains per ear.

The concentrations of nitrogen, phosphorus and potassium established in crop yields show how these essential nutrients were provided at the end of vegetation. Spring wheat yields did not show the dependence of the concentration of these elements on precipitation during vegetation, and in corn only the phosphorus concentration correlated with the sum of active temperatures $\left(\geq 10^{\circ} \mathrm{C}\right)$, especially in later growth stages (Table 6). This shows that in warmer weather spring wheat can absorb phosphorus better (Waqas et al., 2016).

Meanwhile, the sum of active temperatures $\left(\geq 10^{\circ} \mathrm{C}\right)$ in the straw not only influenced the increase of phosphorus concentration, but also partly the nitrogen concentration. The potassium concentration decreased at higher temperatures. This can be explained by the fact that in hot weather and dry soils potassium mobility is less, and less of it moves into mobile and plantshaped forms (Brito et al., 2014).

Summarizing the results of our research and other researchers (Hossain et al., 2012; Rodziewicz et al., 2014; Tammeorg et al., 2014; Trnka et al., 2014; Yadaw, Ellis, 2016), it can be argued that spring wheat is very sensitive to moisture scarcity in the tillers and stem elongation stages, which coincides with the end of May and the 1st ten-day period of June. Lithuania has the least rainfall during this period, and in our research for two years out of five this amount has not been consistent with the multiannual average.

Therefore, more attention must be paid to saving the soil moisture reserves before and after sowing. In the summertime, precipitation is distributed very differently in our climate zone. In each research year, more than $40 \mathrm{~mm}$ of precipitation dropped from the second half of June, and in 2012 it increased even three times. The calculated correlation shows that such an abundant rainfall had a negative effect on spring wheat. The increasing climate change and the associated anomalies force to look for solutions: selection of summer wheat varieties suitable for humid climates and optimal fertilizer rates in avoiding pollution. 
Table 6 . The correlation between nitrogen $(N)\left(y_{1}\right)$, phosphorus $(P)\left(y_{2}\right)$ and potassium $(K)\left(y_{3}\right)$ in the yield of spring wheat and the sum of active temperatures $\left(\geq 10^{\circ} \mathrm{C}\right)$ during the vegetation of plants in the BBCH 37-69 $\left(x_{1}\right)$, 61-89 $\left(x_{2}\right)$ and 21-89 $\left(x_{3}\right)$ growth stages

\begin{tabular}{|c|c|c|c|}
\hline Treatment & Regression equation & $r$ & $x_{\min }-x_{\max }$ \\
\hline \multicolumn{4}{|c|}{ Grain } \\
\hline \multicolumn{4}{|c|}{ (1) Sum of the active temperatures $\left(\geq 10^{\circ} \mathrm{C}\right)$ in the $\mathrm{BBCH} 37-69$ growth stages $\left(x_{1}\right)$} \\
\hline Fertilization 1 & $y_{2}=0.0001 x+0.3934$ & 0.533 & $132-511$ \\
\hline Fertilization 2 & $y_{2}=0.00008 x+0.4077$ & 0.385 & $132-511$ \\
\hline \multicolumn{4}{|c|}{ (2) Sum of the active temperatures $\left(\geq 10^{\circ} \mathrm{C}\right)$ in the BBCH $61-89$ growth stages $\left(x_{2}\right)$} \\
\hline Fertilization 1 & $y_{2}=0.0001 x+0.3421$ & $0.810^{*}$ & $377-988$ \\
\hline Fertilization 2 & $y_{2}=0.0001 x+0.3351$ & $0.972^{* *}$ & $377-988$ \\
\hline \multicolumn{4}{|c|}{ (3) Sum of the active temperatures $\left(\geq 10^{\circ} \mathrm{C}\right)$ in the $\mathrm{BBCH} 21-89$ growth stages $\left(x_{3}\right)$} \\
\hline Fertilization 1 & $y_{2}=0.00009 x+0.2866$ & $0.859^{\star *}$ & $1078-1903$ \\
\hline Fertilization 2 & $y_{2}=0.00009 x+0.2821$ & $0.977^{\star *}$ & $1078-1903$ \\
\hline \multicolumn{4}{|c|}{ Straw } \\
\hline \multicolumn{4}{|c|}{ (4) Sum of the active temperatures $\left(\geq 10^{\circ} \mathrm{C}\right)$ in the BBCH 37-69 growth stages $\left(x_{2}\right)$} \\
\hline Fertilization 1 & $y_{1}=0.0004 x+0.4322$ & 0.486 & $132-511$ \\
\hline Fertilization 2 & $y_{1}=0.0004 x+0.3821$ & 0.344 & $132-511$ \\
\hline \multicolumn{4}{|c|}{ (5) Sum of the active temperatures $\left(\geq 10^{\circ} \mathrm{C}\right)$ in the BBCH $61-89$ growth stages $\left(x_{2}\right)$} \\
\hline Fertilization 1 & $y_{2}=0.00007 x+0.0265$ & $0.787^{\star}$ & $377-988$ \\
\hline Fertilization 2 & $y_{2}=0.00006 x+0.0305$ & 0.573 & $377-988$ \\
\hline \multicolumn{4}{|c|}{ (6) Sum of the active temperatures $\left(\geq 10^{\circ} \mathrm{C}\right)$ in the BBCH $21-89$ growth stages $\left(x_{3}\right)$} \\
\hline Fertilization 1 & $y_{2}=0.00005 x+0.0013$ & 0.754 & $1078-1903$ \\
\hline Fertilization 2 & $y_{2}=0.00004 x+0.009$ & 0.541 & $1078-1903$ \\
\hline \multicolumn{4}{|c|}{ (7) Sum of the active temperatures $\left(\geq 10^{\circ} \mathrm{C}\right)$ in the BBCH $61-89$ growth stages $\left(x_{2}\right)$} \\
\hline Fertilization 1 & $y_{3}=-0.0011 x+1.842$ & $0.927^{\star *}$ & $377-988$ \\
\hline Fertilization 2 & $y_{3}=-0.0009 x+1.6187$ & 0.751 & $377-988$ \\
\hline \multicolumn{4}{|c|}{ (8) Sum of the active temperatures $\left(\geq 10^{\circ} \mathrm{C}\right)$ in the BBCH $21-89$ growth stages $\left(x_{3}\right)$} \\
\hline Fertilization 1 & $y_{3}=-0.0008 x+2.3033$ & $0.908^{* *}$ & $1078-1903$ \\
\hline Fertilization 2 & $y_{3}=-0.0007 x+2.0526$ & $0.778^{*}$ & $1078-1903$ \\
\hline
\end{tabular}

* The indicator corresponds to $05 \%$;

** The indicator corresponds to $01 \%$.

\section{CONCLUSIONS}

1. Applying the Fertilization Program 'Derlius' of the Lithuanian Research Centre for Agriculture and Forestry Agrochemical Laboratory and assessing the concentration of mineral nitrogen, the plantavailable phosphorus and potassium in soil, fertilizer was less used: nitrogen $(\mathrm{N})$ by $15.8 \%$, phosphorus $\left(\mathrm{P}_{2} \mathrm{O}_{5}\right)$ by $81.9 \%$, potassium $\left(\mathrm{K}_{2} \mathrm{O}\right)$ by $41.1 \%$. The spring wheat yields did not decrease, the quality of grain was the same compared with fertilization for obtaining the planned $5 \mathrm{t} \mathrm{ha}^{-1}$ spring wheat grain yield.

2. Five years of research have shown that spring wheat yields were influenced by climatic condi- tions in the eastern part of the Baltic during their growth. The yield of wheat grains and straw and the number of productive stems correlated with the amount of precipitation and active $\left(\geq 10^{\circ} \mathrm{C}\right)$ temperatures during the spring wheat growth stages $\mathrm{BBCH}$ 21-37. Meanwhile, a negative correlation was found between the precipitation and the spring wheat yield in the wheat growth stages BBCH 61-89.

3. The higher sum of active $\left(\geq 10^{\circ} \mathrm{C}\right)$ temperatures increased nitrogen, phosphorus and potassium in straw, and concentrations of phosphorus and potassium in grains.

Received 17 November 2017 Accepted 21 December 2017 


\section{REFERENCES}

1. Brito O. R., Telles T. S., Schnitzer A. J., Gaspar G. G., Guimarães M. F. 2014. The influence of crop residues in vertical soil mobility of potassium. Ciências Agrárias. Vol. 35. No. 6. P. 3043-3051.

2. Bücking H., Kafle A. 2015. Role of arbuscular mycorrhizal fungi in the nitrogen uptake of plants: current knowledge and research gaps. Agronomy. Vol. 5. No. 4. P. 587-612.

3. Campiglia E., Mancinellia R., De Stefanisb E., Pucciarmatib S., Radicettia E. 2015. The longterm effects of conventional and organic cropping systems, tillage managements and weather conditions on yield and grain quality of durum wheat (Triticum durum Desf.) in the Mediterranean environment of Central Italy. Field Crops Research. Vol. 176. P. 34-44.

4. Czaban J., Czyz E., Siebelec G., Niedźwiecki J. 2014. Long-lasting effects of Bentonite on properties of a sandy soil deprived of the humus layer. International Agrophysics. Vol. 28. No. 3. P. 279-289.

5. Dias C. M., Bruggemann W. 2010. Limitations of photosynthesis in Phaseolus vulgaris under drought stress: gas exchange, chlorophyll fluorescence and Calvin cycle enzymes. Photosynthetica. Vol. 48. No. 1. P. 96-102.

6. Dong Ch., Shao L., Fu Y., Wang M., Xie B., Yu J., Liu H. 2015. Evaluation of wheat growth, morphological characteristics, biomass yield and quality in Lunar Palace-1, plant factory, green house and field systems. Acta Astronautica. Vol. 111. P. 102109.

7. Fischer R. A. 2016. The effect of duration of the vegetative phase in irrigated semi-dwarf spring wheat on phenology, growth and potential yield across sowing dates at low latitude. Field Crops Research. Vol. 198. P. 188-199.

8. Fotyma M., Dobers E. S., Breitschuh G., Loide V., Timbare R., Staugaitis G., Spiegel H., Pikula D., Kotvas F., Ceh B., Cermak P., Loch J. 2008. Monography: soil testing methods and fertilizer recommendation in Central-Eastern European countries. Fertilizers and Fertilization. Vol. 30. P. 7-93.

9. García I., Medoza R., Pomar M. C. 2008. Deficit and excess of soil water impact on plant growth of Lotus tenuis by affecting nutrient uptake and arbuscular mycorrhizal symbiosis. Plant and Soil. Vol. 304. No. 1. P. 117-131.

10. Hawkestford J. M. 2014. Reducing the reliance on nitrogen fertilizer for wheat production. Journal of Cereal Science. Vol. 59. No. 3. P. 276-283.

11. Hossain A., Teixeira da Silva J. A., Lozovskaya M. V., Zvolinsky V. P. 2012. High temperature combined with drought affect rainfed spring wheat and barley in South-Eastern Russia: I. Phenology and growth. Saudi Journal of Biological Sciences. Vol. 19. No. 4. P. 473-487.
12. Yadav G., Ellis R. H. 2016. Development of ability to germinate and of longevity in air-dry storage in wheat seed crops subjected to rain shelter or simulated supplementary rainfall. Seed Science Research. Vol. 26. No. 4. P. 332-341.

13. Jiangang L., Guangyao W., Thorp K., Yaoyao Z., Meng Y., Qingquan C. 2015. Effect of nitrogen and water deficit type on the yield gap between the potential and attainable wheat yield. Chilean Journal of Agricultural Research. Vol. 75. No. 4. P. 457-464.

14. Jodaugienė D., Bogužas V., Mikučionienè R., Auželienè I., Zemeckis R. 2015. Effect of crop rotation and preceding crop on nutrient content take out with cereal yield. Žemés ükio mokslai. No. 221. P. 26-35.

15. Karamanos R. E. 2013. Nutrient uptake and metabolism in crops. Prairie Soils and Crops. Vol. 6. P. 52-63.

16. Kawakami J., Iwama K., Jitsuyama Y. 2006. Soil water stress and the growth and yield of potato plants grown from microtubes and conventional seed tubers. Field Crop Research. Vol. 95. P. 89-96.

17. Management of Agroecosystem Components. Results of Long-term Agrochemical Experiments. Compiled by Tripolskaja L., Mašauskas V., Adomaitis T., Karčiauskienè D., Vaišvila Z. 2010. Lithuanian Research Centre for Agriculture and Forestry. 568 p. (in Lithuanian).

18. Mahieu S., Germon F., Aveline A., HauggaardNielsen H., Ambus P., Jensen E. S. 2009. The influence of water stress on biomass and $\mathrm{N}$ accumulation, $\mathrm{N}$ portioning between above and below ground parts and on $\mathrm{N}$ rhizodeposition during reproductive growth of pea (Pisum sativum L.). Soil Biology and Biochemistry. Vol. 41. No. 2. P. 380387.

19. Mondal S., Ghosal S., Barua R. 2016. Impact of elevated soil and air temperature on plants growth, yield and physiological interaction: a critical review. Scientia Agriculturae. Vol. 14. No. 3. P. 293-305.

20. Nakayama N., Saneoka H., Moghaieb R. E. A., Gnasiri S., Fujita P. K. 2007. Response of growth, photosynthetic gas exchange, translocation of 13C-labelled photosynthate and $\mathrm{N}$ accumulation in two soybean (Glycine max L. Merrill) cultivars to drought stress. International Journal of Agriculture and Biology. Vol. 9. No. 5. P. 669-674.

21. Narayanan S., Prasad P. V. 2014. Characterization of a spring wheat association mapping panel for root traits. Agronomy Journal. Vol. 106. No. 5. P. 1593-1604.

22. Nouri E., Breuilin-Sessoms F., Feller U., Reinhardt D. 2014. Phosphorus and nitrogen regulate arbuscular mycorrhizal symbiosis in petunia hybrid. PLoS ONE. Vol. 9. No. 3. Available from: https://doi.org/10.1371/journal.pone.0090841/

23. Parida K. A., Dagaonkar S. V., Phalak S. M., Umalkar V. G., Aurangabadkar P. L. 2007. Alterations 
in photosynthetic pigments, protein and osmotic components in cotton genotypes subjected to short-term drought stress followed by recovery. Plant Biotechnology. Vol. 1. P. 37-48.

24. Pranckietienè I., Mažuolyte-Miškinè E., Pranckietis V., Dromantienè R., Šidlauskas G., Vaisvalavičius R. 2015. The effect of amino acids on nitrogen, phosphorus and potassium changes in spring barley under the conditions of water deficit. Žemdirbystè-Agriculture. Vol. 102. No. 3. P. 265272.

25. Rodziewicz P., Swarcewicz B., Chmielewska K., Wojakowska A., Stobiecki M. 2014. Influence of abiotic stresses on plant proteome and metabolome changes. Acta Physiologiae Plantarum. Vol. 36. No. 1. P. 1-19.

26. Satyaprakash M., Nikitha T., Reddi E. U. B., Sadhana B., Satya Vani S. 2017. Phosphorous and phosphate solubilising bacteria and their role in plant nutrition. International Journal of Current Microbiology and Applied Sciences. Vol. 6(4). P. 2133-2144.

27. Smith E. G., Henry Janzen D., Ellert B. 2017. Effect of fertilizer and cropping system on grain nutrient concentrations in spring wheat. Canadian Journal of Plant Science. Available from: https:// doi.org/10.1139/CJPS-2017-0079

28. Tammeorg P., Simojoki A., Mäkelä P., Stoddard F. L., Alakukku L., Heleniusa J. 2014. Shortterm effects of biochar on soil properties and wheat yield formation with meat bone meal and inorganic fertilizer on a boreal loamy sand. Agriculture, Ecosystems and Environment. Vol. 191. No. 15. P. 108-116.

29. Tesfaye K., Walker S., Tsubo M. 2006. Radiation interception and radiation use efficiency of three grain legumes under water deficit conditions in a semi-arid environment. European Journal of Agronomy. Vol. 25. P. 60-70.

30. Trnka M., Rötter R., Ruiz-Ramos M., Kersebaum K. Ch., Olesen J. E. 2014. Adverse weather conditions for European wheat production will become more frequent with climate change. Nature Climate Change. Vol. 4. P. 637-643.

31. Waqas I., Mukhtar A., Fayyaz-ul-Hassan, Muhammad A., Aslam M. 2016. Models to study phosphorous dynamics under changing climate. In:
Quantification of Climate Variability, Adaptation and Mitigation for Agricultural Sustainability. P. 371-386.

32. Zörb C., Senbayramb M., Peiterc E. 2014. Potassium in agriculture - status and perspectives. Journal of Plant Physiology. Vol. 171. No. 9. P. 656-669.

33. Zorn W., Albert E., Kolbe H., Kerschberger M., Franke G. 2007. Düngung in Thüringen 2007 nach „Guter fachlicher Praxis“. Türinger Landesabstalt für Landwirtschaft. P. 154-155. Available from: www.tll.de/ainfo/pdf/dung0108.pdf (in German).

\section{Gediminas Staugaitis, Loreta Aleknavičienė, Zita Brazienè, Antanas Marcinkevičius \\ KLIMATINIŲ SĄLYGŨ IR SKIRTINGAIS METODAIS APSKAIČIUOTŲ TRĄŠŲ NORMŲ ITAKA VASARINIŲ KVIEČIŲ DERLIUI}

Santrauka

2011-2015 m. Lietuvos agrarinių ir miškų mokslų centro Rumokų bandymų stotyje, gerai sukultūrintame giliai glèjiškame karbonatingame išplautžemyje (IDk-g0), vykdyti lauko eksperimentai, kurių tikslas - nustatyti klimatinių sąlygu ir skirtingais metodais apskaičiuotų trąšų normų ịtaką vasarinių kviečių derliui. Tyrimai parodė, kad taikant Lietuvos agrarinių ir miškų mokslų centro Agrocheminių tyrimų laboratorijos programą „Derlius" vasariniams kviečiams tręšti per penkerius metus vidutiniškai 15,8 \% mažiau sunaudota azoto trąšu, 81,9 \% - fosforo, 41,1 \% - kalio, palyginti su trąšu normomis $5 \mathrm{t} \mathrm{ha}^{-1}$ planuojamam grūdu derliui gauti. Penkerių metų tyrimai atskleidè, kad vasarinių kviečių derlingumui Baltijos jūros rytinëje dalyje ženklios itakos turi jų augimo metu esamos klimatinès sąlygos. Grūdų ir šiaudų derlius, produktyvių stiebų skaičius koreliavo su vasarinių kviečių per vegetaciją iškritusių kritulių kiekiu ir didesne aktyvių temperatūrų suma $\mathrm{BBCH}$ 21-37 augimo tarpsniais. Neigiama koreliacija nustatyta BBCH 61-89 tarpsniais tarp išritusio didelio kritulių kiekio ir vasarinių kviečių derliaus. Penkerių metų vidutiniai duomenys parodè, kad vasarinių kviečių augimo metu didesnè aktyvių $\left(\geq 10^{\circ} \mathrm{C}\right)$ temperatūrų suma didino šiauduose azoto, fosforo ir kalio, o grūduose - fosforo ir kalio koncentracijas.

Raktažodžiai: oro sąlygos, tręšimas, vasariniai kviečiai, azotas, fosforas, kalis 